DOI: https://doi.org/10.24127/ajpm.v8i3.2473

\title{
PENINGKATAN KECERDASAN INTRAPERSONAL DAN HASIL BELAJAR MELALUI MODEL PEMBELAJARAN TAKE AND GIVE BERBASIS MATEMATIKA REALISTIK
}

\author{
Lylo Paradita ${ }^{1}$, Ira Vahlia ${ }^{2}$, Yeni Rahmawati ES ${ }^{3^{*}}$ \\ ${ }^{1,2,3}$ Pendidikan Matematika,Universitas Muhammadiyah Metro \\ *Corresponding author. Address: Department of Mathematics Education, Muhammadiyah University of Metro, \\ 34111, Lampung, Indonesia \\ E-mail: $\quad$ nengdita21@gmail.com ${ }^{1)}$ \\ iravahlia768@yahoo.co.id ${ }^{2)}$ \\ yeni.rahmawati1988@yahoo.com ${ }^{3 * 1}$
}

Received 8 November 2019; Received in revised form 6 December 2019; Accepted 25 December 2019

\begin{abstract}
Abstrak
Tujuan dari penelitian ini adalah untuk meningkatkan kecerdasan intrapersonal dan hasil belajar siswa melalui model pembelajaran take and give berbasis matematika realistik. Jenis penelitian ini adalah penelitian tindakan kelas dengan subyek penelitian adalah siswa kelas VII SMP Darma Bakti Punggur Tahun Pelajaran 2018/2019 yang terdiri 15 siswa. Dari hasil penelitian dan pembahasan, terlihat adanya peningkatan kecerdasan intapersonal dan hasil belajar matematika siswa pada pembelajaran yang dilakukan. Hal ini dapat diketahui dari peningkatan persentase ketiga indikator kecerdasan intrapersonal yaitu mengenali diri sendiri meningkat sebesar 6,67\%, mengetahui yang diinginkan meningkat sebesar $6,67 \%$ dan mengetahui apa yang penting dalam diri sendiri meningkat sebesar $13,33 \%$. Selain itu peningkatan persentase rata-rata kecerdasan intrapersnonal sebesar 84,45\% menjadi 93,33\% serta 15 siswa mengalami peningkatan kecerdasan intrapersonal. Untuk hasil belajar matematika dapat dilihat dari peningkatan rata-rata ketuntasan tiap pertemuan pada siklus I dan siklus II. Selain itu untuk rata-rata ketuntasan secara klasikal meningkat sebesar 93,33\%.
\end{abstract}

Kata kunci: hasil belajar; kecerdasan intrapersonal; matematika realistik; model take and give.

\begin{abstract}
The purpose of this study was to improve interpersonal intelligence and learning outcomes through take and give learning model based on realistic mathematic. The type of this research is classroom action research with the research subjects being seventh-grade students of Darma Bakti Punggur Middle School 2018/2019 Academic Year consisting of 15 students. From the results of the research and discussion, it is seen that there is an increase in interpersonal intelligence and the results of students' mathematics learning in the learning done. This can be seen from the increase in the percentage of the three indicators of interpersonal intelligence, namely recognizing yourself increased by 6.67\%, knowing what was desired increased by $6.67 \%$ and knowing what was important in yourself increased by $13.33 \%$. Also, the increase in the average percentage of interpersonal intelligence was $84.45 \%$ to $93.33 \%$, and 14 students experienced an increase in interpersonal intelligence. For mathematics learning outcomes can be seen from an increase in the completeness of each meeting in the first cycle and second cycle. In addition to the average completeness in classics increased by $93.33 \%$.
\end{abstract}

Keywords : interpersonal intelligence; learning outcomes; realistic mathematics; take and give model.

\section{PENDAHULUAN}

Tujuan pendidikan adalah menciptakan pribadi berkualitas dan memiliki karakter sehingga mempunyai visi yang luas kedepan untuk menggapai cita-cita yang diharapkan serta mampu beradaptasi dalam berbagai lingkungan. Pendidikan sangat dibutuhkan guna untuk mempersiapakan masa depan anakanak indonesia menjadi lebih baik. 
DOI: https://doi.org/10.24127/ajpm.v8i3.2473

Disadari atau tidak, matematika sangat penting sebagai alat bantu dalam memecahkan masalah-masalah dalam kehidupan sehari-hari. Oleh karena itu, siswa dituntut untuk dapat menguasai materi matematika. Akan tetapi ternyata tidak semua siswa dapat menguasai materi matematika. Hal ini dapat ditunjukkan dari hasil belajar matematika ulangan tengah semester genap kelas VIIA SMP Darma Bakti Punggur Lampung Tengah Tahun Pelajaran 2017/2018 pada Tabel 1.

Tabel 1. Data nilai ulangan tengah semester

\begin{tabular}{|c|c|c|c|c|}
\hline No & Nilai & Keterangan & Frekuensi & $(\%)$ \\
\hline 1 & $\geq 63$ & Tuntas & 3 & 16,7 \\
\hline 2 & $<63$ & $\begin{array}{l}\text { Tidak } \\
\text { tuntas }\end{array}$ & 15 & 83,3 \\
\hline \multicolumn{3}{|c|}{ Jumlah } & 18 & $100 \%$ \\
\hline
\end{tabular}

Berdasarkan Tabel 1, terlihat bahwa $83,3 \%$ siswa kelas VIIA belum memenuhi KKM. Ini berarti bahwa sebagian besar siswa belum menguasai materi yang telah disampaikan. Selanjutnya dilakukan pra-survei terhadap kecerdasan intrapersonal siswa. Ada 3 aspek yang digunakan untuk melihat kecerdasan intrapersonal yakni mengenali diri sendiri, mengetahui yang diinginkan, dan mengetahui apa yang penting dalam diri sendiri. Berikut adalah data hasil pra survei kecerdasan intrapersonal siswa yang dilakukan di kelas VII A dengan jumlah siswa 18 orang.

Berdasarkan Tabel 2 dapat dilihat bahwa untuk setiap aspek, persentase siswa yang mengenali diri sendiri, mengetahui yang diinginkan dan mengetahui apa yang penting dalam diri sendiri masih sangat rendah. Hal ini menunjukkan rendahnya kecerdasan intrapersonal siswa.
Tabel 2. Data awal kecerdasan intrapersonal siswa.

\begin{tabular}{clcc}
\hline No & $\begin{array}{l}\text { Aspek yang } \\
\text { diamati }\end{array}$ & $\begin{array}{c}\text { Banyak } \\
\text { Siswa }\end{array}$ & Persentase \\
\hline 1. & $\begin{array}{l}\text { Mengenali } \\
\text { diri sendiri }\end{array}$ & 5 & $27,78 \%$ \\
2. & $\begin{array}{l}\text { Mengetahui } \\
\text { yang } \\
\text { diinginkan } \\
\text { Mengetahui } \\
\text { apa yang } \\
\text { penting dalam } \\
\text { diri sendiri. }\end{array}$ & 5 & $27,78 \%$ \\
\hline
\end{tabular}

Salah satu inovasi dalam pembelajaran agar dapat meningkatkan kecerdasan intrapersonal dan hasil belajar matematika adalah memilih model pembelajaran. Model pembelajaran yang dipilih harus dapat mengembangkan kemampuan siswa untuk menginterpretasikan suatu permasalahan ke dalam bentuk matematika dengan baik dan dapat meningkatkan kecerdasan intrapersonal siswa. Inovasi pembelajaran yang sesuai dengan permasalahan yang ditemukan adalah model pembelajaran take and give berbasis matematika realistik karena pembelajaran tersebut menekankan keterkaitan antara materi dengan pengalaman sehari-hari.

Pembelajaran dengan model pembelajaran take and give adalah pemberian kartu yang bertujuan agar siswa saling berbagi materi, melatih siswa terlibat menyampaikan dan menerima materi dari siswa lain secara berulang-ulang agar siswa menjadi lebih aktif. Guru melakukan evaluasi pada siswa di akhir pembelajaran dengan cara menanyakan apa yang didapatkan dari siswa lainnya. Fadila \& Indrawati (2014) Model pembelajaran kooperatif tipe Take and Give untuk membantu siswa memperdalam dan mempertajam materi pelajaran serta meningkatkan skill dasar, pencapaian, interaksi positif antar siswa, harga diri dan sikap penerimaan pada 
siswa-siswa lain yang berbeda. Model pembelajaran take and give memiliki beberapa kelebihan. Hal ini seperti yang dijelaskan Udayanti \& Riastini (2017) kelebihan model pembelajaran take and give adalah sebagai berikut: 1) perserta didik akan lebih cepat memahami penguasaan materi dan informasi, karena mendapatkan informasi dari guru dan peserta didik, 2) dapat menghemat waktu dalam pemahaman dan penguasaan peserta didik akan informasi, 3) meningkatkan kemampuan untuk bekerja sama dan bersosialisasi, 4) melatih kepekaan diri, empati melalui variasi perbedaan sikap dan tingkah laku selama bekerja, 5) upaya mengurangi rasa kecemasan dan menumbuhkan rasa percaya diri, 6) meningkatkan motivasi belajar, sikap dan tingkah laku yang positif serta meningkatkan prestasi belajar.

Widari, dkk (2013) menjelaskan bahwa dalam pendekatan matematika realistik siswa diberikan kesempatan sendiri untuk menemukan ide maupun konsep-konsep, dimana dalam konsep ini diawali dengan masalah realistik. Sedangkan Saharah, dkk (2016) Pembelajaran dengan menggunakan pendekatan matematika realistik dirancang berawal dari pemecahan masalah yang ada di sekitar siswa dan berbasis pada pengetahuan yang telah dimiliki oleh siswa, sehingga diharapkan dapat meningkatkan pemahaman matematika siswa. Dalam pembelajaran matematika realistik, permasalahan realistik digunakan sebagai fondasi dalam membangun konsep matematika, kemudian definisi akhir, sifat dan teorema dapat ditemukan. Matematika realistik adalah suatu pembelajaran yang dapat membantu siswa lebih mudah memahami suatu mater ikarena materi yang akan disampaikan ada keterkaitannya dalam kehidupan seharihari yang dialamai oleh siswa.

Kecerdasan yang dimiliki oleh seseorang tidak hanya dapat dilihat dari segi akademik, tetapi dapat juga dilihat dari sisi kecerdasan yang lain. Misalnya adalah kecerdasan intrapersonal. Kecerdasan intrapersonal mempunyai peran penting dalam kehidupan seharihari. Utami (2012) menjelaskan bahwa kecerdasan intrapersonal berkaitan dengan pemahaman dan penyesuaian terhadap diri sendiri. Dengan kata lain, kecerdasan intrapersonal meliputi kemampuan yang berkaitan dengan keadaan manusia secara internal, yaitu yang berkaitan dengan refleksi diri, berpikir meta-kognisi, menyadari adanya kenyataan spiritual. Kemampuan tersebut akan dibutuhkan oleh manusia dalam menjalani kehidupan. Sedangkan Krobo (2014) memaparkan bahwa kecerdasan intrapersonal yang kuat menempatkan kita untuk kesuksesan.

Kecerdasaan intrapersonal juga ikut mempengaruhi hasil belajar matematika siswa. Hal ini senada dengan yang dipaparkan Zefanya (2018) semakin tinggi tingkat kecerdasan intrapersonal dan kedisiplinan belajar siswa, akan semakin tinggi pula prestasi belajar matematika siswa. Hal ini disebabkan siswa yang memiliki kecerdasan intrapersonal akan jauh lebih bertanggung jawab terhadap dirinya sendiri sehingga siswa tersebut akan memiliki kesadaran dan tanggung jawab terhadap dirinya sendiri untuk terus memperbaiki dan meningkatkan kualitas belajarnya.

Pelaksanaan model pembelajaran take and give berbasis matematika realistik diawali dengan penjelasan materi yang terkait dalam kehidupan sehari-hari siswa oleh guru, pemberian kartu dengan materi yang terkait dalam 
kehidupan sehari-hari siswa, sub materi semua siswa berbeda dalam setiap kelompok, hal ini bertujuan memberi kesempatan siswa untuk mempelajari materinya sehingga dapat dijelaskan pada kelompoknya. Dengan demikian, diharapkan setelah dilaksanakan model pembelajaran take and give kecerdasan intrapersonal dan hasil belajar matematika siswa dapat lebih maksimal.

Berdasarkan uraian latar belakang masalah di atas, maka tujuan penelitian ini yaitu untuk mengetahui peningkatan pelaksanaan model pembelajaran take and give berbasis matematika realistik terhadap kecerdasan intrapersonal dan hasil belajar siswa

\section{METODE PENELITIAN}

Jenis penelitian ini adalah Penelitian Tindakan Kelas (PTK), yang meliputi 4 langkah yakni: perencanaan, pelaksanaan tindakan, pengamatan, dan refleksi. Penelitian ini dilakukan sebanyak 2 siklus, masing-masing siklus terdiri dari 3 pertemuan. Materi yang disampaikan tentang aritmatika sosial.

Penelitian ini dilaksanakan di SMP Darma Bakti Punggur Lampung Tengah. Subjek penelitian tindakan kelas ini adalah seluruh siswa kelas VII A SMP Darma Bakti Punggur Tahun Pelajaran 2018/2019. Jumlah siswa sebanyak 15 orang.

Teknik pengumpulan data yang digunakan dalam penelitian ini adalah tes, angket dan observasi. Tes yang digunakan untuk mengukur ketuntasan hasil belajar siswa berupa soal essay. Angket digunakan untuk mengukur kecerdasan intrapersonal siswa berupa item-item pernyataan sebanyak 20 butir. Sedangkan observasi digunakan untuk mencatat dan mengetahui pembelajaran yang berlangsung dari segi guru maupun siswa berupa lembar observasi.

Analisis data yang digunakan untuk menghitung persentase jumlah siswa yang memenuhi KKM dan persentase target kecerdasan intrapersonal adalah sebagai berikut:

$$
P=\frac{\mathrm{F}}{\mathrm{N}} \times 100 \%
$$

Dengan keterangan:

$\mathrm{P}=$ Angka persentase

$\mathrm{F}=$ Frekuensi siswa yang memenuhi KKM/ Frekuensi siswa yang menjawab item angket pada tiap indikator

$\mathrm{N}=$ Jumlah individu

Lima aspek model pembelajaran take and give berbasis matematika realistik yang digunakan dalam penelitian ini antara lain: informasikan kompetensi, menyajikan materi, pemantapan materi, evaluasi, refleksi. Adapun langkah-langkah penerapan model pembelajaran take and give berbasis matematika realistik dalam penelitian ini dapat dilihat pada Tabel 3. 
DOI: https://doi.org/10.24127/ajpm.v8i3.2473

Tabel 3. Langkah-langkah penerapan model pembelajaran take and give berbasis matematika realistik

\begin{tabular}{|c|c|c|}
\hline No & Aspek & Langkah-Langkah Pembelajaran \\
\hline 1. & Informasikan Kompetensi & $\begin{array}{l}\text { a. Membuat kartu berisikan nama siswa, bahan belajar (sub } \\
\text { materi) dan nama yang diberikan informasi, serta soal } \\
\text { dalam masalah kehidupan sehari-hari siswa } \\
\text { b. Menyiapkan kelas dengan baik }\end{array}$ \\
\hline 2. & Menyajikan Materi & $\begin{array}{l}\text { Guru memberikan contoh atau masalah yang berkaitan } \\
\text { dengan masalah kontekstual }\end{array}$ \\
\hline 3. & Pemantapan Materi & $\begin{array}{l}\text { a. Guru memberikan kartu untuk dikerjakan secara mandiri } \\
\text { b. Guru memberikan waktu berfikir untuk mengerjakan } \\
\text { masalah-masalah yang ada dalam kartu } \\
\text { c. Siswa mempergunakan waktu yang telah diberikan guru } \\
\text { untuk memikirkan penyelesain masalah yang ada } \\
\text { d. Siswa bergabung dengan pasangannya masing-masing } \\
\text { dengan pengorganisasian dari guru yang telah ditetapkan } \\
\text { sebelumnya } \\
\text { e. Siswa mempergunakan waktu yang telah diberikan guru } \\
\text { untuk saling bertukar informasi mengenai masing-masing } \\
\text { masalah yang telah diberikan serta memperbaiki masalah } \\
\text { yang kurang tepat dengan pasangannya. } \\
\text { f. Siswa membagikan informasi yang telah disampaikan } \\
\text { oleh teman satu kelompok kepada kelompok lain dengan } \\
\text { mencatat nama siswa lain didalam kartu yang telah } \\
\text { diberikan, sampai semua siswa dapat saling menerima } \\
\text { dan memberi materi masing-masing }\end{array}$ \\
\hline 4. & Evaluasi & $\begin{array}{l}\text { Guru mengevaluasi pemahaman siswa mengenai meteri } \\
\text { dengan memberikan siswa sebuah pertanyaan yang ada } \\
\text { pada kartu kelompok lain. }\end{array}$ \\
\hline
\end{tabular}

5. Refleks

Siswa bersama guru menyimpulkan materi

Indikator keberhasilan dalam penelitian ini adalah sebagai berikut:

1. Data diperoleh dari proses pembelajaran berupa kecerdasan intrapersonal selama tindakan. Pada penelitian ini, indikator keberhasilan kecerdasan intrapersonal yang ingin dicapai pada akhir siklusnya menurut Krobo (2014) yang tersaji pada Tabel 4.

2. Peningkatan hasil belajar melalui model pembelajaran take and give berbasis matematika realistik dilihat dengan adanya ketuntasan hasil belajar pada akhir siklus menurut Sepharyanto, dkk (2017) minimal $\geq 85 \%$

Tabel 4. Indikator keberhasilan kecerdasan intrapersonal

\begin{tabular}{clc}
\hline No & \multicolumn{1}{c}{$\begin{array}{c}\text { Aspek yang } \\
\text { diamati }\end{array}$} & Target \\
\hline 1. & $\begin{array}{l}\text { Mengenali diri } \\
\text { sendiri }\end{array}$ & $\geq 82,13 \%$ \\
2. & $\begin{array}{l}\text { Mengetahui yang } \\
\text { diinginkan }\end{array}$ & $\geq 82,13 \%$ \\
3. & $\begin{array}{l}\text { Mengetahui apa } \\
\text { yang penting } \\
\text { dalam diri sendiri. }\end{array}$ \\
\hline
\end{tabular}


DOI: https://doi.org/10.24127/ajpm.v8i3.2473

\section{HASIL PENELITIAN DAN PEMBAHASAN}

\section{Kecerdasan Intrapersonal}

Kecerdasan intrapersonal siswa dalam pembelajaran pada siklus I yang diperoleh dari angket dapat dilihat pada Tabel 5. Berdasarkan Tabel 5, peningkatan pada aspek mengenali diri sendiri dan aspek mengetahui yang diinginkan sudah mencapai indikator keberhasilan yang ingin dicapai tetapi pada aspek mengetahui apa yang penting dalam diri sendiri belum mencapai indikator keberhasilan dikarenakan kesadaran diri siswa dalam memahami arti sebuah pembelajaran belum tumbuh. Diperkuat dengan dilihatnya hasil observasi dalam pembelajaran siswa belum terfokus pada penjelasan materi yang disampaikan oleh guru.

Tabel 5. Data angket kecerdasan intrapersonal siklus I

\begin{tabular}{llcc}
\hline No & \multicolumn{1}{c}{ Aspek yang diamati } & $\begin{array}{c}\text { Persentase } \\
\text { siklus I }\end{array}$ & Target \\
\hline 1. & Mengenali diri sendiri & $86,67 \%$ & $\geq 82,13 \%$ \\
2. & Mengetahui yang diinginkan & $86,67 \%$ & $\geq 82,13 \%$ \\
3. & $\begin{array}{l}\text { Mengetahui apa yang penting dalam } \\
\text { diri sendiri. }\end{array}$ & $80 \%$ & $\geq 82,13 \%$ \\
\hline
\end{tabular}

Selanjutnya, oleh karena ada aspek kecerdasan intrapersonal yang belum memenuhi indikator keberhasilan maka dilakukan siklus II. Adapun data yang diperoleh dari angket pada siklus II dapat dilihat pada Tabel 6.

Tabel 6. Data angket kecerdasan intrapersonal siklus II

\begin{tabular}{llcc}
\hline No & \multicolumn{1}{c}{ Aspek yang diamati } & $\begin{array}{c}\text { Persentase } \\
\text { siklus II }\end{array}$ & Target \\
\hline 1. & Mengenali diri sendiri & $93,33 \%$ & $\geq 82,13 \%$ \\
2. & Mengetahui yang diinginkan & $93,33 \%$ & $\geq 82,13 \%$ \\
3. & $\begin{array}{l}\text { Mengetahui apa yang penting dalam diri } \\
\text { sendiri. }\end{array}$ & $93,33 \%$ & $\geq 82,13 \%$ \\
\hline
\end{tabular}

Berdasarkan data pada Tabel 6, semua aspek kecerdasan intrapersonal sudah mencapai indikator keberhasilan yang ditentukan. Pada aspek mengetahui apa yang penting dalam diri sendiri sudah mencapai indikator keberhasilan yang ingin dicapai, indikator keberhasilan dapat dicapai karena kesadaran diri siswa dalam memahami arti sebuah pembelajaran sudah tumbuh dan dalam pembelajaran siswa sudah terfokus pada penjelasan guru.

Adapun perbandingan data kecerdasan intrapersonal siswa dari pra PTK sampai siklus II dapat dilihat pada Tabel 7. 
DOI: https://doi.org/10.24127/ajpm.v8i3.2473

Tabel 7. Persentase hasil angket kecerdasan intrapersonal pada pra PTK, siklus I dan siklus II

\begin{tabular}{llcccc}
\hline No & \multicolumn{1}{c}{ Aspek yang diamati } & Pra PTK & $\begin{array}{c}\text { Persentase } \\
\text { siklus I }\end{array}$ & $\begin{array}{c}\text { Persentase } \\
\text { siklus II }\end{array}$ & Peningkatan \\
\hline 1. & Mengenali diri sendiri & $27,78 \%$ & $86,67 \%$ & $93,33 \%$ & $6,67 \%$ \\
2. & $\begin{array}{l}\text { Mengetahui yang } \\
\text { diinginkan }\end{array}$ & $44,45 \%$ & $86,67 \%$ & $93,33 \%$ & $6,67 \%$ \\
$\begin{array}{l}\text { Mengetahui apa yang } \\
\text { penting dalam diri sendiri. }\end{array}$ & $27,78 \%$ & $80 \%$ & $93,33 \%$ & $13,33 \%$ \\
\hline & Berdasarkan Tabel 7, dapat & $\begin{array}{l}\text { adanya pembelajaran yang lebih pada } \\
\text { kehidupan sehari-hari. }\end{array}$ &
\end{tabular}

diketahui bahwa kecerdasan intrapersonal anak dari sebelum tindakan sampai dengan siklus II menunjukkan peningkatan. Pada aspek mengenali diri sendiri pra penelitian $27,78 \%$, siklus I sebesar 86,67 \%, dan siklus II sebesar 93,33\%. Pada aspek Mengetahui yang diinginkan pra penelitian 44,45 \%, siklus I sebesar 86,67 \%, dan siklus II sebesar 93,33 $\%$. Pada aspek mengetahui apa yang penting dalam diri sendiri pra penelitian $27,78 \%$, siklus I sebesar $80 \%$ dan siklus II sebesar 93,33 \%. Dengan demikian dapat dikatakan bahwa kecerdasan intrapersonal siswa dapat meningkat setelah diterapkan model pembelajaran take and give berbasis matematika realistik.

Kecerdasan intrapersonal siswa dapat meningkat dengan diterapkannya pembelajaran bermain peran (Krobo, 2014). Mubarokah (2014) menyatakan bahwa penerapan model pembelajaran kooperatif take and give pada kelas eksperimen dapat mendorong siswa lebih aktif di kelas seperti aktif dalam diskusi kelompok yaitu saling memberi dan menerima. Pada pembelajaran take and give membuat interaksi antara siswa dan guru berjalan seperti yang diharapkan. Siswa sudah memahami arti sebuah pembelajaran, pemahaman materi siswa lebih melekat berkat

\section{Hasil Belajar Matematika}

Penilaian hasil belajar siswa pada siklus I didasarkan pada kemampuan kognitif siswa dalam mengerjakan soal yang diberikan. Data hasil belajar matematika siswa pada tes siklus I dapat dilihat pada Tabel 8 .

Tabel 8. Data hasil belajar matematika pada test siklus I.

\begin{tabular}{|c|c|c|c|c|}
\hline No & Nilai & Kriteria & $\begin{array}{c}\text { Jumlah } \\
\text { siswa }\end{array}$ & Persentase \\
\hline 1. & $\geq 63$ & Tuntas & 13 & $86,77 \%$ \\
\hline 2. & $>63$ & $\begin{array}{l}\text { Tidak } \\
\text { tuntas }\end{array}$ & 2 & $13,33 \%$ \\
\hline \multicolumn{3}{|c|}{ Jumlah } & 15 & $100 \%$ \\
\hline
\end{tabular}

Berdasarkan Tabel 8, tingkat kemampuan siswa dalam mengerjakan soal diukur dari tingkat ketuntasan. Pada penelitian ini kriteria keberhasilan adalah ketuntasan hasil belajar siswa mencapai $\geq 85 \%$ di atas KKM (63). Hasil analisis tes hasil belajar pada siklus I mencapai 86,77 \% dengan perincian dari 15 siswa sebanyak 13 siswa mendapatkan nilai di atas KKM dan 2 siswa mendapatkan nilai di bawah KKM. Berdasarkan hasil tes akhir siklus I ini dikatakan bahwa ketuntasan hasil belajar siswa sudah memenuhi kriteria keberhasilan tindakan atau indikator keberhasilan. 
DOI: https://doi.org/10.24127/ajpm.v8i3.2473

Meskipun hasil belajar pada siklus I sudah memenuhi indikator keberhasilan, namun tetap diberikan tes hasil belajar pada siklus II. Hal ini untuk lebih menyakinkan lagi bahwa model pembelajaran take and give berbasis matematika realistik dapat meningkatkan hasil belajar siswa. Adapun data hasil belajar matematika pada siklus II dapat dilihat pada Tabel 9.

Tabel 9. Data hasil belajar matematika mengerjakan test siklus II.

\begin{tabular}{lcccc}
\hline No. & Nilai & Kriteria & Jumlah siswa & Persentase \\
\hline 1. & $\geq 63$ & Tuntas & 14 & $93,33 \%$ \\
2. & $>63$ & Tidak tuntas & 1 & $6,67 \%$ \\
& Jumlah & 15 & $100 \%$ \\
\hline
\end{tabular}

Berdasarkan Tabel 9, analisis tes hasil belajar pada siklus II mencapai 93,33\%, dengan perincian dari 15 siswa sebanyak 14 siswa mendapatkan nilai di atas KKM dan 1 siswa mendapatkan nilai di bawah KKM. Berdasarkan hasil tes akhir siklus II ini dikatakan bahwa ketuntasan hasil belajar siswa sudah memenuhi kriteria keberhasilan tindakan. Adapun perbandingan ratarata hasil belajar siswa pada siklus I dan II dapat dilihat pada Tabel 10

Tabel 10. Perbandingan rata-rata hasil belajar siswa siklus I dan siklus II

\begin{tabular}{ccccc}
\hline Indikator & Target & Siklus I & $\begin{array}{c}\text { Siklus } \\
\text { II }\end{array}$ & Peningkatan \\
\hline Ketuntasan hasil belajar & $\geq 85 \%$ & $86,77 \%$ & $93,33 \%$ & $6,56 \%$ \\
\hline
\end{tabular}

Pada Tabel 10 tampak báhwa siklus I Persentase yang diperoleh sebesar $86,77 \%$ melebihi indikator keberhasilan yang ingin dicapai. Pada siklus II meningkat sebesar $6,56 \%$ sehingga menjadi 93,33\%.

Fadila \& Indrawati (2014) model pembelajaran take and give dapat meningkatkan hasil belajar siswa baik itu aspek kognitif, afektif dan psikomotorik. Hal ini sejalan dengan (Sepharyanto dkk, 2017) Pembelajaran kooperatif tipe Take and Give merupakan salah satu pembelajaran yang dapat meningkatkan hasil belajar siswa dan juga dapat melatih dan meningkatkan kerjasama dan sikap sosial pada diri siswa.

Anisa (2015) memaparkan bahwa pembelajaran pendidikan matematika realistik dengan prinsip yaitu menggunakan masalah kontekstual, menggunakan model, menggunakan kontribusi dan produksi siswa, proses pembelajaran yang interaktif, dan keterkaitan antar topik memberikan kontribusi positif terhadap sikap siswa. Sedangkan Saharah, dkk (2016) Pembelajaran pendekatan matematika realistik ternyata dapat meningkatkan kemandirian siswa dan rasa percaya diri untuk menyelesaikan tugas yang diberikan sehingga mereka termotivasi untuk meningkatkan hasil belajar mereka.

Peningkatan hasil belajar matematika disebabkan kesadaran diri siswa memahami arti sebuah pembelajaran sudah tumbuh dan dapat menerima pendapat atau masukan dari teman maupun guru. Peningkatan hasil belajar terjadi karena proses pembelajaran pada siklus Il dilakukan upaya-upaya memperbaiki pencapaian 
DOI: https://doi.org/10.24127/ajpm.v8i3.2473

target indikator kecerdasan intrapersonal dan hasil belajar yang belum tercapai pada siklus I setelah melakukan evaluasi pada akhir siklus I.

\section{KESIMPULAN DAN SARAN}

Berdasarkan hasil penelitian tindakan kelas, dapat disimpulkan bahwa pembelajaran matematika dengan model pembelajaran take and give berbasis matematika realistik yang dilakukan di kelas VII A SMP Darma Bakti Punggur semester genap tahun pelajaran 2018/2019 dapat meningkatkan kecerdasan intrapersonal siswa dan hasil belajar matematika siswa.

Dengan memperhatikan hasil penelitian dan pembahasan, saran yang dapat diberikan sebagai berikut: 1) harus lebih cermat dalam mengalokasikan waktu selama proses pembelajaran berlangsung. Hal ini disebabkan agar waktu yang digunakan tidak hanya untuk diskusi dalam menyelesaikan persoalan pada kartu, sehingga pembahasan soal secara bersama-sama berjalan dengan lancar, 2) Guru dalam menyampaikan materi harus menarik, simpel, mempunyai aturan yang jelas agar siswa tidak mengalami kesulitan dalam menyelesaikan kartu.

\section{DAFTAR PUSTAKA}

Anisa, W. N. (2015). Peningkatan Kemampuan Pemecahan Masalah dan Komunikasi Matematik Melalui Pembelajaran Pendidikan Matematika Realistik Untuk Siswa SMP Negeri Di Kabupaten Garut. Jurnal Penelitian Pendidikan dan Pengajaran Matematika, 1(1), 73-82.
Fadila, N \& Indrwati, V. (2014). Penerapan Model Pembelajaran Kooperatif Tipe Take And Give Pada Kompetensi Dasar Teknik Pengolahan Makanan Untuk Meningkatkan Hasil Belajar Siswa Kelas X Jasa Boga 3 Smk Negeri 2 Boyolangu. Journal Boga, 3(3), 58-67.

Krobo, A. (2014). Peningkatan Kecerdasan Intrapersonal Melalui Kegiatan Bermain Peran. Jurnal Pendidikan Usia Dini, 8(1), 2534.

Mubarokah, R. (2014). Penerapan Model Pembelajaran Kooperatif Take And Give Terhadap Kemampuan Pemahaman Konsep Kelas VII. Jurnal Delta. 2(2), 3541.

Saharah, dkk. (2016). Penerapan Pendekatan Matematika Realistik Untuk Meningkatkan Hasil Belajar Siswa Kelas 1 SD Integral Rahmatullah Tolitoli Pada Materi Penjumlahan Dan Pengurangan Bilangan. Jurnal Kreatif Tadulako, 4(3), 178 - 192.

Sepharyanto, dkk. (2017). Upaya Meningkatkan Hasil Belajar Siswa Kelas IV Melalui Pembelajaran Kooperatif Tipe Take and Give dan Quick On The Draw. Jurnal Pendidikan : Teori, Penelitian, dan Pengembangan. 2(4), 579-591.

Udayanti, I.A.G.S. \& Riastini, P. N. (2017). Penerapan Metode Take And Give Untuk Meningkatkan Hasil Belajar IPA Siswa Kelas IVA. Jurnal Ilmiah Sekolah Dasar, 1(1), 51-58. DOI: $\underline{10.23887 / j i s d . v 1 i 1.10118}$ 
DOI: https://doi.org/10.24127/ajpm.v8i3.2473

Utami, A. D. (2012). Peningkatan Kecerdasan Intrapersonal Dan Kecerdasan Interpersonal Melalui Pembelajaran Project Approach. Jurnal Ilmiah VISI, 7(2), 138-152. DOI: https://doi.org/10.21009/JIV .0702

Widari, I G. A., dkk. (2013). Penerapan Pendekatan Pembelajaran Matematika Realistik Sebagai Upaya Meningkatkan Aktivitas Dan Prestasi Belajar Siswa Dalam Pembelajaran Bangun Ruang Pada Siswa Kelas IVA SDN 9 Sesetan Tahun Pelajaran 2011/2012. Jurnal Santiaji Pendidikan, 3(2).
Zefanya, F. (2018). Pengaruh Kecerdasan Intrapersonal Dan Kedisiplinan Belajar Terhadap Prestasi Belajar Matematika. JKPM (Jurnal Kajian Pendidikan Matematika), 3(2). DOI : 10.30998/jkpm.v3i2.2772 